\title{
MENYOAL BUKU AJAR KEAGAMAAN: Tadqiq Buku Mata Kuliah Pendidikan Agama Islam di Universitas Negeri Gorontalo
}

\section{QUESTIONING RELIGIOUS TEXTBOOK: \\ Tadqiq of Islamic Education Course Books at The State University of Gorontalo}

\author{
Idham \\ Balai Penelitian dan Pengembangan Agama Makassar \\ Jl. A. P. Pettarani No. 72 Makassar \\ Email: idbodi@yahoo.co.id
}

Naskah diterima 20 Februari 2016, direvisi 3 Maret 2016, disetujui 30 Maret 2016

\begin{abstract}
This study investigates religious textbook particularly Islamic Study subject at the University of Gorontalo (UNG), with the desire to answer two research questions, namely: 1) How is the textbook of Islamic Religious Education at the State University of Gorontalo (UNG) used? and 2) How is the content of the textbook of Islamic religious education in UNG viewed in the perspective of tadqiq ?. This study used qualitative descriptive analysis. The text data of textbook was analyzed by stages that refer to the stages of tadqiq selected by using content analysis. The results showed that the Islamic Study textbook published in 2009 has been in accordance with the Decree of Directorate General of Higher Education NO. 43 / DIKTI / Kep / 2006. There are additions and subtractions, but do not reduce the content of the book. The course book is used for teaching at 11 faculties in UNG, regardless of the type of faculty and discipline. In addition, the book is printed for limited purpose (in this case for students). In terms of tadqiq, this textbook has some weaknesses, such as: it does not use transliteration, there are a few typos, it is inconsistent in quoting and translation, the hadist that are used do not meet the standard of writing (sanad, honor, narrators), do not have harakat, only the translation is given, and there is an expression that is considered a hadist, and so forth.
\end{abstract}

Keywords: Tadqiq, textbooks, religious education

\section{Abstrak}

Penelitian ini menyoal buku ajar keagamaan khususnya Matakuliah Agama Islam di Universitas Gorontalo (UNG), dengan keinginan menjawab dua pertanyaan penelitian, yaitu: 1) Bagaimana mekanisme penggunaan buku ajar Pendidikan Agama Islam di Universitas Negeri Gorontalo (UNG)? dan 2) Bagaimana isi buku ajar pendidikan agama Islam di UNG dalam perspektif tadqiq?. Penelitian ini menggunakan analisis deskriptif kualitatif. Adapun data teks buku ajar dianalisis dengan tahapan yang mengacu pada tahapantahapan tadqiq yang dipilih dengan menggunakan analisis isi. Hasil penelitian menunjukkan bahwa Buku Matakuliah Pendidikan Agama Islam yang diterbitkan pada tahun 2009 ini telah sesuai dengan Surat Keputusan Direktorat Jendral Pendidikan Tinggi No. 43/DIKTI/Kep/2006. Ada penambahan dan pengurangan, namun tidak mengurangi konten buku tersebut. Buku matakuliah tersebut diajarkan pada 11 Fakultas di UNG, tanpa memerhatikan jenis fakultas dan kelokalannya. Selain itu, buku ini dicetak sangat terbatas (kalangan sendiri). Dari segi tadqiq, buku matakuliah ini memiliki beberapa kekurangan, seperti: Belum menggunakan transliterasi, ada beberapa kesalahan ketik, tidak konsisten dalam pengutipan ayat dan terjemahnya, hadis yang digunakan belum memenuhi standar penulisan (sanad, matan, perawi), tidak berharakat, ada yang mencantumkan hanya terjemahannya, dan ada ungkapan yang disinyalir sebagai hadis, dan lainlain.

Kata Kunci : Tadqiq, buku ajar, pendidikan keagamaan 


\section{PENDAHULUAN}

Upaya membangun moral bangsa berdasarkan UUD 1945, Visi dan Misi dan Pendidikan Nasional serta regulasi-regulasi turunannya, yang pada intinya bardasar pada Ketuhanan Yang Maha Esa dengan menciptakan manusia yang berakhlak mulia, maka pendidikan agama seharusnya menjadi prioritas utama oleh pemerintah. Berdasarkan Undang-undang Nomor 20 Tahun 2003 Tentang Sistem Pendidikan Nasional Pasal 12 ayat 1, "Adalah hak setiap peserta didik mendapatkan pendidikan agama sesuai dengan agama yang dianutnya dan diajarkan oleh pendidik yang seagama." ${ }^{1}$

Perhatian stakeholder akan keberadaan pendidikan agama masih menjadi prioritas kedua di berbagai lembaga pendidikan, termasuk perguruan tinggi. Misalnya, minimnya alokasi jam, pendekatan yang dikotomis antara pendidikan agama dan disiplin ilmu lainnya, materi dianggap terlalu normatif tanpa ilustrasi konteks budaya, serta tidak jelasnya panduan baku yang berlaku. Belum lagi jika dilihat dari fasilitas perpustakaan yang sangat minim menyediakan buku-buku Islam.

Hasil penelitian Bidang Kehidupan Agama dan Keagamaan Balai Litbang Agama Makassar pada tahun 2015 tentang "Pergeseran Faham Keagamaan Mahasiswa Di Kampus Kawasan Timur Indonesia”, menunjukkan adanya sikap abai dari kampus akan pentingnya pendidikan agama. Oleh karena itu, ruang kosong ini dimanfaatkan oleh kelompok-kelompok radikal dan kelompok yang mencoba mengubah dasar negara Pancasila dengan mengisi wacana

1 Undang-undang Nomor 20 Tahun 2003 Tentang Sistem Pendidikan Nasional. keagamaan di kampus, sehingga mereka mampu mendominasi baik dalam kegiatan maupun buku-buku keagamaan yang beredar. ${ }^{2}$

Selama ini, perhatian peneliti lebih besar pada buku teks di SD sampai SMU. Perhatian terhadap perguruan tinggi sangat minim disebabkan otonomi yang tinggi yang diberikan pada perguruan tinggi untuk menetapkan kurikulum dan buku ajar yang hendak diajarkan di kampus. Kebijakan ini merupakan kebijakan positif agar kampus bisa mandiri menetapkan kurikulum sendiri. Di sisi lain, bisa menjadi negatif apabila pihak kampus abai akan pentingnya pendidikan agama di kampus dan meyerahkan sepenuhnya pada tenaga dosen sehinggi fungsi kontrol lembaga perguruan tinggi menjadi tidak berjalan. Faktor lain yang turut andil meminimalisir sorotan tersebut yaitu budaya kebebasan berpikir di kampus. Berdasarkan argumen tersebut, penelitian ini diadakan oleh Bidang Lektur dan Khazanah Keagamaan Balai Litbang Agama Makassar mengadakan penelitian ini dengan menfokuskan pada matakuliah agama Islam di perguruan tinggi umum dengan sasaran buku Matakuliah Pendidikan Agama Islam di Universitas Negeri Gorontalo. Penelitian ini berlangsung selama 18 hari di bulan Maret dan April tahun 2016.

Berdasarkan latar belakang tersebut, maka yang menjadi inti penelitian ini adalah buku ajar keagamaan khususnya matakuliah agama Islam di Universitas Gorontalo (UNG), khususnya dari segi tadqiq. Masalah pokok ini lalu diuraikan

2 Laporan hasil penelitian Balitbang Agama Makassar. 2015. Pergeseran Faham Keagamaan Mahasiswa Di Kampus Kawasan Timur Indonesia. Makassar: Balitang Agama Makassar. 
ke dalam pertanyaan penelitian yaitu: 1) Bagaimana mekanisme penggunaan buku ajar Pendidikan Agama Islam di Universitas Negeri Gorontalo (UNG)? Dan 2) Bagaimana isi buku ajar pendidikan agama Islam di UNG dalam perspektif tadqiq?

Penelitian ini difokuskan pada pentadqiq-an Buka Ajar Pendidikan Agama Islam di Perguruan Tinggi (Universitas Negeri Gorontalo). Buku ajar yang dimaksudkan adalah buku Matakuliah yang ditulis dan menjadi pegangan dosen Agama Islam dalam mengajarkan matakuliah agama di UNG. Adapun yang dimaksud pen-tadqiq-an adalah menyunting konten buku matakuliah tersebut, meliputi: transliterasi, penulisan ayat dan terjemah, penulisan hadis serta sumber dan terjemahnya, penulisan rujukan, dan sistematika penulisan.

\section{Tinjauan Pustaka}

Kegiatan pentashihan buku telah dilakukan Badan Litbang dan Diklat dalam bentuk Keputusan Kepala Badan Litbang Agama dan Diklat Keagamaan Nomor BD/01/2004 $4^{3}$ tentang Pedoman Penulisan, Penerbitan dan Pentashihan Buku-buku Keagamaan. Meski telah lama dilakukan, kegiatan pentashihan buku nampaknya belum begitu populer di kalangan masyarakat luas, termasuk di lingkungan Kementerian Agama sendiri ${ }^{4}$.

${ }^{3}$ Keputusan Kepala Badan Litbang Agama dan Diklat Keagamaan No. BD/01/2004, Tanggal 5 Februari 2004 tentang Pedoman Penulisan, Penerbitan, dan Pentashihan Buku-Buku Keagamaan.

${ }^{4}$ Asep Saefullah dan Masmedia Pinem (Ed.), 2007.Panduan Pentashihan Buku Keagamaan. Jakarta: Puslitbang Lektur Keagamaan Badan Litbang dan Diklat, Jakarta, h. 17.
Pada tahun anggaran 2006, Puslitbang Lektur Keagamaan (Tim Tashih Pusat) telah menerima 83 buku untuk ditashih, yang berasal dari Kanwil Departemen Agama Provinsi DKI Jakarta (37 buku), Kanwil Departemen Agama Provinsi Jawa Barat (2 buku), dan Kanwil Departemen Agama Provinsi Jawa Timur (44 buku). Buku-buku tersebut seluruhnya buku pelajaran agama untuk tingkat Madrasah Ibtidaiyah sampai dengan Madrasah Aliyah, yaitu Fikih, AlQur'an-Hadis, Sejarah Kebudayaan Islam, Akidah-Akhlak, dan Bahasa Arab. Dari hasil penelitian dan pemeriksaan terhadap bukubuku yang masuk tersebut, pada umumnya masih terdapat kesalahan serupa dengan kesalahan yang ada pada buku-buku yang diajukan sebelumnya. Hanya saja tiap buku tentunya memiliki kuantitas dan kualitas kesalahan yang berbeda-beda, mulai dari yang tinggi sampai dengan yang rendah. Jenis kesalahan yang ditemukan meliputi: 1) ketidaktepatan pengutipan teks ayat Al-Qur'an; 2) ketidaktepatan pengutipan teks hadis; 3) ketidaktepatan pengutipan terjemah ayat Al-Qur'an; 4) ketidaktepatan penerjemahan hadis; dan 5) inkonsistensi dalam penggunaan transliterasi Arab-Latin. ${ }^{5}$

Selain beberapa kesalahan pokok yang ditemukan sebagaimanan tersebut di atas, masih banyak juga dijumpai kesalahan-kesalahan teknis lainnya, seperti ketidaktepatan penulisan Bahasa Indonesia, ketidaksesuaian antara pengutipan ayat AlQur'an atau hadis dengan topik bahasan, ketidaksesuaian antara materi dengan gambar (ilustrasi), dan ketidaksesuaian

${ }^{5}$ Munawiroh. 2009. "Kajian atas Buku Teks Pendidikan Agama Islam pada Madrasah Ibtidaiyah", dalam Jurnal Lektur Keagamaan,Vol. 7, No. 2, h. 293-312 
antara materi dengan soal latihan, walaupun berdasarkan KMA No. 437 Tahun $2001^{6}$, halhal tersebut tidak menjadi tanggung jawab Tim Tashih, akan tetapi tetap diberikan saran dan masukan kepada pihak pemohon (penerbit). ${ }^{7}$

Pada tahun 2008, Puslitbang Lektur Keagamaan kembali melakukan survei atas buku Pendidikan Agama Islam (PAI) yang digunakan di Madrasah Ibtidaiyah di wilayah Jakarta, Bekasi, Tangerang, dan Depok. Temuan penelitian ini antara lain masih terdapat kesalahan terkait dengan penulisan dan pengutipan ayat Al-Qur'an dan hadis, kebenaran terjemah, kesesuaian ayat/hadis serta penggunaan transliterasi Arab-Latin, secara garis besar dapat dikategorikan kepada tiga hal: 1) Menggunakan acuan di luar Keputusan Bersama Menteri Agama RI No 158 tahun 1987 dan Menteri Pendidikan dan Kebudayaan RI Nomor 0543/b/1987 untuk penulisan Transliterasi Arab-Latin; 2) Menggunakan acuan bukan Keputusan Menteri Agama RI Nomor 437 Tahun 2001 untuk pengutipan ayat Al-Qur'an serta Terjemahan ayat-ayatnya; 3) Belum mengimplementasikan Keputusan Kepala Badan Litbang Agama dan Diklat Keagamaan No. BD/01/2004 tentang Pedoman Penulisan. salain itu, permaslahan yang lain yang adalah 1) Tidak tepat dalam mengutip ayat Al-Qur'an, terjemahan, penulisan matan atau teks hadis dan penggunaan transliterasi, serta kesalahan dalam penulisan kata atau

${ }^{6}$ Keputusan Mentari Agama Republik Indonesia, No. 437 Tahun 2001, Tanggal 8 Oktober 2001 tentang Pentashihan Buku-Buku yang Memuat Tulisan AyatAyat Al-Qur'an yang Diterbitkan, dan Diadakan di Lingkungan Depertemen Agama.

${ }^{7}$ Munawiroh. 2009. "Kajian atas Buku Teks Pendidikan Agama Islam pada Madrasah Ibtidaiyah”, dalam Jurnal Lektur Keagamaan,Vol. 7, No. 2, h. 293-312 pemberian harakat karena tidak sesuai dengan acuan yang ditetapkan oleh penerbit sendiri; 2) Tidak tepat dalam mentranslterasi ayat Al-Qur'an, bagi penerbit yang telah menggunakan pedoman tersebut sebagai acuan dalam penerbitannya; 3) Adanya buku agama yang dibeli belum memperoleh tashih dari unit yang berwenang (Kementerian Agama). ${ }^{8}$

\section{Teori Tadqiq}

Teori yang digunakan dalam penelitian ini yaitu teori tadqiq. Istilah tadqiq secara umum masih kurang dikenal karena belum baku dalam bahasa Indonesia. Terminologi yang digunakan dalam menyunting teks lebih dikenal istilah reviuw atau suntingan. Puslitbang Lektur dan Khazanah Kegamaan sendiri mengunakan tiga terminologi dalam penyuntingan teks keagamaan. Dalam halini, terminologi dibedakan hanya berdasarkan pada objek kajiannya saja. Tashih digunakan dengan objeknya Al Qur'an, tahqiq dengan objeknya naskah kuno atau manuskrip dan tadqiq dengan objeknya lektur kontemporer.

Dari ketiga terminologi tersebut, tahapan metode tahqiq nampaknya lebih mapan, jelas dan rinci dari yang lain. Istilah tahqiq merupakan bagian dari metode filologi yang dikenal juga dengan istilah kritiks teks, yaitu analisis yang memberikan evaluasi terhadap teks, meneliti dan menempatkan teks pada tempatnya yang tepat. Kegiatan kritiks teks bertujuan menghasilkan teks sedekat-dekatnya dengan teks aslinya. Untuk mencapai tujuan tersebut teks diberikan catatan

${ }^{8}$ Munawiroh. 2009. "Kajian atas Buku Teks Pendidikan Agama Islam pada Madrasah Ibtidaiyah", dalam Jurnal Lektur Keagamaan,Vol. 7, No. 2, h. 293-312 
tambahan berupa perbaikan terhadap kesalahan-kesalahan (corrupt) pada teks serta catatan tambahan lainnya. Teks yang sudah dibersihkan dari kesalahan-kesalahan dan telah tersusun kembali seperti semula dapat dipandang sebagai tipe mula (arketip) yang dapat dipertanggungjawabkan sebagai sumber untuk kepentingan berbagai penelitian dalam bidang ilmu-ilmu lain. ${ }^{9}$

Kritik teks juga dikenal dengan tahqiq alnusus. Kata tahqiq berasal dari bahasa Arab. Sementara disiplin ilmu yang mempelajari tentang tahqiq ini disebut ilm tahqiq al-nusus. Tahqiq terhadap naskah bertujuan untuk menentukan suatunaskah mendekatinaskah aslinya atau naskah yang sebagaimana pertama kali ditulis oleh pengarangnya ${ }^{10}$.

Penelitian dalam bidang pentahqiqan sebelum berkembang di Eropa, para ilmuwan Arab klasik telah melakukannya terlebih dahulu sebelum pada akhirnya dikembangkan oleh ilmuwan-ilmuwan kontemporer Eropa hingga saat ini. Pada awalnya ilmuwan-ilmuwan Arab klasik melakukannya dengan cara membandingkan antara beberapa teks yang berbeda, dari segi periwayatannya sehingga teks-teks tersebut dapat ditentukan tingkat kebenarannya antara satu dengan yang lainnya. Seperti pen-tahqiq-an yang telah dilakukan oleh Ali bin Muhammad bin Abdullah (wafat tahun $107 \mathrm{H}$ ), terhadap periwayatan kitab Sahih al-Bukhari, yang ditulis oleh alBukhari, sehingga muncullah kitab-kitab

${ }^{9}$ Siti Barorah Baried. et al., 1994. Pengantar Teori Filologi (Yoyakarta: Badan Penelitian dan dan Publikasi Fakultas Seksi Filologi Fakultas Sastra Universitas Gadjah Mada, h. 61.

10 Ramada>n 'Abd al-Tawwa>b. 1985.Manahij Tahqiq al-Turas Bain al-Qudama Wa al-Muhdasin. Kairo: Maktabah al-khanijiy, h. 5. yang menjelaskan tentang Sahih al-Bukhari sebagai penjelasan terhadap hal-hal yang masih dianggap kabur (belum jelas) dalam kitab tersebut. ${ }^{11}$

Sedangkan perhatian para pakar di Eropa terhadap kegiatan kritik teks baru terjadi pada abad ke-15 M. seiring dengan berkembangnya sastra Yunani dan Latin. Sebelumnya, para ilmuwan Eropa ketika menemukan naskah-naskah klasik, mereka langsung mencetaknya tanpa melakukan pencarian terhadap naskah (teks) lain yang sejenis dengan teks tersebut untuk dibandingkan antara satu dengan yang lain. Namun dengan perkembangan ilmu filologi di Eropa, para filolog mulai mengumpulkan teks-teks klasik tersebut kemudian membandingkannya, ketika terjadi perbedaan antara teks-teks itu, maka mereka memilih salah satu darinya untuk dijadikan patokan atau landasan utama dalam men-tahqiq dan teks-teks yang lain dijadikan penjelasan pada catatan kaki (footnote). Apa yang dilakukan oleh filolog Eropa ini, sedikit berbeda dengan pentahqiq-kan yang dilakukan oleh filolog Arab klasik. Hal ini terjadi, karena filolog Eropa belum memiliki metode dan aturan-aturan dalam mentahqi>q sebuah teks, fenomena ini berlangsung hingga pertengahan abad ke-19, karena dasar-dasar ilmiah kritik naskah (text criticism) baru diletakkan pada abad ini. Mengacu pada metode teori

${ }^{11}$ Badri Yunardi. 2005. "Pokok-Pokok Pikiran tentang Pengembangan Tugas Pentashihan BukuBuku Keagamaan", disampaikan pada Workshop Pedoman Pentashihan Buku Keagamaan, Puslitbang Lektur Agama, tanggal 29-30 Nopember 2005 di Gedung Bayt Al-Qur'an dan Museum Istiqlal, TMI, Jakarta 
tahqiq di atas, penelitian tadqiq ini mencoba mengadopsi sebagian tahapan-tahapan yang dianut oleh metode tahqiq atau kritik teks.

\section{METODOLOGI PENELITIAN}

Penelitian ini adalah penelitian deskriptif kualitatif dengan melakukan penelusuran dan pentadqiqan pada buku ajar (matakuliah) Pendidikan Agama Islam yang disusun dan digunakan di Perguruan Tinggi Universitas Negeri Gorontalo, dan selanjutnya disunting dengan menggunakan tahapan yang ditentukan. Khusus untuk data teks buku ajar dianalisis dengan tahapan yang mengacu pada tahapan-tahapan tadqiq yang dipilih sebagai berikut: a) Mendeskrispi buku ajar Pendidikan Agama Islam; b) Menyusun tema-tema bahasan serta menyunting kesesuaian konten bahasan dan tema pada buku teks; c) Menyunting kesesuaian konten dengan regulasi yang berlaku; d) Menyunting transliterasi ArabLatin dalam buku teks; e) Menyunting kutipan ayat Al Qur'an dan terjemahannya dalam buku teks; f) Menyunting kutipan hadis dan terjemahannya dalam buku teks; g) Menyunting kesesuaian kutipan Al Qur'an dan Hadis dengan tema bahasan; h) Menyunting daftar kutipan dan teknik pengutipan dalam buku teks.

\section{HASIL DAN PEMBAHASAN}

\section{Setting Lokasi Universitas Negeri Gorontalo}

Provinsi Gorontalo adalah hasil pemekaran dari provinsi Sulawesi Utara berdasarkan UU RI No. 38 Tahun $2000 .{ }^{12}$

\footnotetext{
${ }^{12}$ UU RI No. 38 Tahun 2000 tentang pembentukan Provinsi Gorontalo.
}

Provinsi Gorontalo memiliki dua perguruan tinggi negeri, yakni Universitas Negeri Gorontalo (UNG) dan Institut Agama Islam Negeri (IAIN) Sultan Amai Gorontalo. Universitas Negeri Gorontalo (UNG) merupakan universitas yang dikembangkan atas dasar perluasan mandat (wider mandate) dari IKIP Negeri Gorontalo. Keberadaan Universitas Negeri Gorontalo dimulai dari Junior College FKIP Universitas Sulawesi Utara-Tengah (UNSULUTTENG) Manado yang awalnya berstatus swasta. Berdasarkan Surat Keputusan Menteri Pendidikan Tinggi dan Ilmu Pengetahuan No. 22 Tahun 1961 tertanggal 4 Juli 1961 resmi berubah status menjadi universitas negeri. Selanjutnya, berdasarkan Instruksi Menteri Pendidikan Tinggi dan Ilmu Pengetahuan (PTIP) Nomor 5 Tahun 1962, UNSULUTTENG merencanakan membuka Junior College atau Extention Course di beberapa kota daeran Provinsi Sulawesi Utara-Tengah. ${ }^{13}$

Perjalanan selanjutnya, ${ }^{14}$ pada tahun 1964 satusnya berubah menjadi Cabang IKIP Yogyakarta Cabang Manado. Pertengahan tahun 1965, setelah IKIP Manado berdiri sendiri, lembaga ini menjadi salah satu cabangnya dan berganti nama menjadi

${ }^{13}$ http://www.ung.ac.id/profil/visimisi diunduh tanggal 21 April 2016

${ }^{14}$ berdasarkan surat keputusan pejabat Rektor UNSULUTTENG Nomor 1313/II/E/63 tanggal 22 Juni 1963, Cabang FKIP UNSULUTTENG di Gorontalo berdasarkan Surat Keputusan Menteri PTIP nomor 67 tahun 1963 tanggal 11 Juli 1963, IKIP Manado Cabang Gorontalo berdasarkan Surat Keputusan Menteri PTIP Nomor 114 tahun 1965 tanggal 18 Juni 1965, FKIP UNSRAT Manado di Gorontalo berdasarkan Keppres nomor 70 tahun 1982 tanggal 7 September 1982, STKIP Gorontalo berdasarkan Kepres RI nomor 9 tahun 1993 tanggal 16 Januari 1993, IKIP Negeri Gorontalo berdasarkan Kepres RI nomor 19 tahun 2001 tanggal 5 Februari 2001. 
IKIP Manado Cabang Gorontalo yang membina 4 Fakultas dengan 13 Jurusan. Pada tahun 1982 lembaga ini dialihkan dari IKIP Manado menjadi salah satu Fakultas dari Universitas Sam Ratulangi (Unsrat) Manado dengan nama Fakultas Keguruan dan Ilmu Pendidikan (FKIP) Unstrat Manado di Gorontalo.

Berdasarkan PP Nomor 30 Tahun 1990, maka pada tahun 1993, lembaga ini resmi berdiri dengan nama Sekolah Tinggi Keguruan dan Ilmu Pendidikan (STKIP) Gorontalo yang ditetapkan dengan Keppres RI Nomor: 9 Tahun 1993 tertanggal 26 Januari 1993. Menyadari terbatasnya ruang lingkup STKIP sejajar tuntutan kebutuhan masyarakat dan Pemerintah Daerah, maka pada tahun 2001 dengan keluarnya Keppres RI Nomor: 19 Tahun 2001 tertanggal 5 Februari 2001 status lembaga ini ditingkatkan menjadi IKIP Negeri Gorontalo yang membina 5 Fakultas dengan 25 Program Studi. ${ }^{15}$

Perubahan IKIP Negeri Gorontalo menjadi Universitas Negeri Gorontalo ditetapkan dengan surat Keputusan Presiden RI nomor 54 tahun 2004 tanggal 23 Juni 2004. Hari lahir UNG ditetapkan sama dengan lahirnya cabang FKIP UNSULUTTENG di Gorontalo yaitu, tanggal 1 September 1963 sebagaimana dinyatakan dalam surat keputusan menteri PTIP nomor 67 tahun 1963 tanggal 11 Juli 1963. Dalam perjalanannya selama 50 tahun telah mengalami tujuh kali pergantian pimpinan dan enam kali perubahan nama lembaga. Secara rinci nama pejabat pimpinan sejak tahun 1963 - sampai sekarang sbb : 1)Drs. Idris Djalali - Dekan

${ }^{15}$ Hasanuddin, dkk. 2012. Sejarah Pendidikan di Gorontalo. Yogyakarta: Kepel Presss, h. 147-150.
Koordinator IKIP Yogyakarta Cab. Manado di Gorontalo - 1963-1966; 2) Drs. Ek. M. J. Neno - Dekan Koordinator IKIP Manado Cab. Gorontalo - 1967-1969; 3) Prof. Drs. H. Thahir A. Musa - Dekan Koordinator IKIP Manado Cab. Gorontalo - 1969-1981; 4) Prof. Drs. H. Kadir Abdussamad - Dekan FKIP Unsrat Manado di Gorontalo - 1982-1988; 5) Drs. H. Husain Jusuf, M.Pd - Dekan FKIP Unsrat Manado di Gorontalo - 1989-1992; 6) Prof. Dr. H. Nani Tuloli Dekan FKIP Unsrat Manado di Gorontalo - 1992-1993, Ketua STKIP Negeri Gorontalo - 1993 - 2001, Pj. Rektor IKIIP Negeri Gorontalo - 2001 - 2002; 7) Prof. Dr. Ir. H. Nelson Pomalingo, M.Pd Rektor IKIP Negeri Gorontalo - 2002-2004, Rektor Universita Negeri Gorontalo - 2004-2010; dan 8) Dr. H. Syamsu Qamar Badu, M.Pd Rektor Universita Negeri Gorontalo - 2010 sampai sekarang.

Universitas Negeri Gorontalo (UNG) kini berkembang pesat menyamakan posisinya dengan perguruan-perguruan tinggi negeri lainnya di Indonesia. Dengan visi dan misinya. Visi: Leading University dalam Pengembangan Kebudayaan dan Inovasi berbasis potensi Regional di Kawasan Asia Tenggara. Adapun Misi: a) Menyiapkan SDM berpendidikan tinggi yang mempunyai kapasitas keilmuan, moralitas, leadership, etos kewirausahaan dan soft skills; b) Meningkatkan kualitas pembelajaran, penelitian dan pengabdian masyarakat yang mendukung daya saing bangsa serta memperkokoh budaya lokal dan identitas nasional; c) Mengembangkan partnership dan networks yang mendukung penerapan sains dan teknologi, inovasi-inovasi berbasis potensi regional, dan pengembangan kebudayaan; d) Membangun produk-produk akademik yang didukung oleh pemanfaatan 
teknologi informasi, lingkungan kampus yang aman, nyaman dan produktif. ${ }^{16}$

Pembangunan pisik kampus UNG berkembang pesat dibarengi pengembangan SDM. UNG yang berada di tengah kota Gorontalo (Jalan Jend. Sudirman No. 6), kini memiliki 19.050 Mahasiswa(i) yang tersebar pada 11 Fakultas dan 59 Program Studi. Komposisi mahasiswa berdasarkan agama, dapat dilihat pada tabel berikut:

Tabel 1

Komposisi Mahasiswa berdasarkan Agama

\begin{tabular}{|c|c|c|c|c|c|}
\hline \multirow{2}{*}{ No } & \multirow{2}{*}{ Agama } & \multicolumn{2}{|c|}{ Jenis Kelamin } & \multirow{2}{*}{ Jumlah } & \multirow{2}{*}{$\%$} \\
\hline & & Laki-Laki & Perempuan & & \\
\hline 1 & Islam & 8.003 & 10.627 & 18.630 & 97.795 \\
\hline 2 & Protestan & 107 & 105 & 212 & 1.113 \\
\hline 3 & Katolik & 10 & 9 & 19 & 0.010 \\
\hline 4 & Hindu & 98 & 82 & 180 & 0.945 \\
\hline 5 & Buddha & 4 & 4 & 8 & 0.042 \\
\hline 6 & $\begin{array}{l}\text { Aliran } \\
\text { kepercayaan }\end{array}$ & 1 & - & 1 & 0.005 \\
\hline \multicolumn{4}{|c|}{ Jumlah mahasiswa keseluruhan } & 19.050 & 100 \\
\hline
\end{tabular}

Sumber: BAK UNG

Adapun dosen yang tersedia atau yang terdaftar sebanyak 767 orang (707 orang dosen aktif dan 60 orang dosen sedang tugas belajar). Adapun dosen agama sebanyak 9 orang yang tersebar pada beberapa fakultas. Kesembilan dosen Pendidikan Agama Islam di UNG, yaitu: 1) Dr. Nur Kasim, MH (FH), ketua Prodi PPs Hukum; 2) Dr. Nofri Djefri, M.Pd. (FIP), sekertaris Jurusan Managemen Pendidikan; 3) Dr. Munkizul Uman, M.Phil. (FBS), kepala asrama; 4) Yowan Tamu, M.A. (FIS), wakil dekan III; 5) Lukman Katili, M.Th.I. (FIS), ka. Laboratorium Sosial; 6) Aqil Bahsoan, M.Ag. (FED), Sekertaris Jurusan Pendidikan Ekonomo; 7) Suyono Dude,

${ }^{16}$ http://www.ung.ac.id/profil/visimisi diunduh tanggal 21 April 2016
M.Pd.I, F (Fak. Pertanian), sekretaris Jurusan Pertanian; 8) Syamsi Pomalingo, M.A. (FIP); dan 90 Nurhayati Tine, M.Hi. (FIP)

Pada dosen agama Islam tersebut tersebar pada beberapa fakultas. Selain itu, para pimpinan fakultas memberdayakan guru agama Islam dengan memberikan tuhas tambahan difakultas masing-masing.

\section{Menyoal Buku Ajar PAI di UNG: Deskripsi dan Penggunaan}

Pendidikan Agama Islam di Universitas Gorontalo sudah ada sejak berdirinya perguruan tinggi ini. Akan tetapi sebelum tahun 2009, mata kuliah tersebut diajarkan berdasarkan selera masing-masing dosen, tanpa buku pegangan, sama halnya dengan perguruan tinggi umum lainnya di Indonesia. ${ }^{17}$ Berdasarkan fenomena tersebut, maka pendidikan agama di perguruan tinggi diatur oleh Keputusan Direktur Jenderal Pendidikan Tinggi Departemen Pendidikan Nasional RI Nomor: 43/DIKTI/Kep/2006 tentang Rambu-Rambu Pelaksanaan Kelompok Matakuliah Pengembangan Kepribadian di Perguruan Tinggi. Salah satu matakuliah kelompok pengembangan tersebut adalah matakuliah agama.

Adapun visi kelompok matakuliah pengembangan kepribadian (MPK) adalah terdapat dalam pasal 1 yang berbunyi: Visi kelompok MPK di perguruan tinggi merupakan sumber nilai dan pedoman dalam pengembangan program studi guna mengantarkan mahasiswa memantapkan kepribadiannya sebagai Indonesia seuruhnya. Sedangkan misi

${ }^{17}$ Wawancara Agil Bahsoan, dosen matakuliah Pendidikan Agama Islam di UNG. Wawancara pada tanggal 29 Maret 2016 di Rektorat UNG. 
kelompok matakuliah pengembangan kepribadian (MPK) dapat dilihat pada pasal 2 yang berbunyi: Misi kelompok MPK di perguruan tinggi membantu mahasiswa memantapkan kepribadiannya agar secara konsisten mempu mewujudkan nilai-nilai dasar keagamaan dan kebudayaan, rasa kebangsaan dan cinta tanah air sepanjang hayat dalam menguasai, menerapkan dan mengembangkan ilmu pengetahuan, teknologi dan seni yang dimilikinya dengan rasa tanggung jawab.

Melihat visi dan misi MPK di perguruan tinggi sebagaimana pada pasal 1 dan 2 di atas, maka diharapkan matakuliah MPK ini dapat mengantarkan mahasiswa memantapkan kepribadiannya sebagai bangsa Indonesia dan membantu mahasiswa memantapkan kepribadian agar konsisten dalam mewujudkan nilai-nilai keagamaan dan kebudayaannya. Matakuliahyang masuk dalam kelompok mata kuliah kepribadian adalah pendidikan agama, pendidikan kewarganegaraan, dan pendidikan bahasa Indonesia (pasal 3 ayat 2). ${ }^{18}$

Setelah terbitnya Keputusan Dirjen Dikti Nomor 43 tahun 2006 di atas, maka dalam para dosen agama dituntut membuat buku mata kuliah pendidikan agama Islam di perguruan tingginya. Pemerintah dalam hal ini Kementerian Agama maupun Kementerian Pendidikan dan Kebudayaan telah banyak mengadakan pelatihanpelatihan dalam rangka memotivasi dan merangsang para dosen untuk membuat buku matakuliah pendidikan agama Islam tersebut. Hasil dari pelatihan-pelatihan

\footnotetext{
${ }^{18}$ Keputusan Dirjen Dikti Nomor: 43/DIKTI/ Kep/2006 dengan isi buku mata kuliah Pendidikan Agama Islam untuk Perguruan Tinggi Umum.
}

tersebut, maka para dosen Agama Islam di Universitas Negeri Gorontalo pada tahun 2008 membentuk tim pembuatan buku matakuliah agama tersebut. Tidak lebih dari satu tahun, draft buku pun siap cetak. ${ }^{19}$

Mata Kuliah Pendidikan Islam Untuk Perguruan Tinggi Umum, seperti itulah nama buku tersebut yang terbit pada bulan Februari 2009. Cetakan pertama ini diterbitkan oleh UNG Press yang beralamat di Kampus UNG Jl. Jend. Sudirman No. 6 Kota Gorontalo. Buku ini tanpa ISBN dan tanpa kata sambutan, yang ada adalah kata pengantar penyusun tertanggal 29 Januari 2009. Buku ini terdiri atas 262+vii halaman. Buku mata kuliah ini disusun empat orang ini, yakni: Drs. Darwin Une, M.Pd., Agil Bahsoan, S.Ag., M.Ag., Lukman D. Katili, S.Ag., M.Th.I., dan Nur Muhammad Kasim, S.Ag.,M.Ag.

Buku ini berpenampilan sederhana dengan sampul berwarna putih dan hijau. Ilustrasi gambar sampul depan adalah kubah makam Rasulullah saw dengan sebuah menara. Adapun punggung buku tertulisakan judul pendidikan agama Islam dan tim penyusun. Sistem penjilidan buku ini adalah dengan paku hetter dan lem.

Menurut penyusun buku ini, buku ini disusun berdasarkan amanat Keputusan Direktur Jenderal Pendidikan Tinggi Departemen Pendidikan Nasional RI Nomor: 43/DIKTI/Kep/2006. Pernyataan tersebut sebagaimana yang tertera pada kata pengantar paragraf ketiga:

${ }^{19}$ WawancaraLukman D. Katili, dosen matakuliah Pendidikan Agama Islam di UNG. Wawancara pada tanggal 29 Maret 2016 di Rektorat UNG. 
Sebagai ilustrasi, sesungguhnya bahan ajar Matakuliah Pendidikan Agama Islam yang telah kami susun ini, sudah sesuai dengan substansi kajian kelompok Mata Kuliah Pengembangan Kepribadian (MPK) sebagaimana amanat Keputusan Direktur Jenderal Pendidikan Tinggi Departemen Pendidikan Nasional Republik Indonesia nomor: 43/DIKTI/Kep/2006, tentang Rambu-Rambu Pelaksanaan Kelompok Matakuliah Pengembangan Kepribadian di Perguruan Tinggi, yaitu: Tuhan Yang Maha Esa dan Ketuhanan, Manusia, Hukum, Moral, Ilmu Pengetahuan, Teknologi dan Seni, Kerukunan antar Ummat beragama, Masyarakat, Budaya dan Politik. ${ }^{20}$

Walaupun buku ini disusun berdasarkan Keputusan Dirjen Dikti Nomor: 43/DIKTI/ Kep/2006 dengan muatan sebagaimana yang terdapat pada pasal 4 tentang substansi kajian Kelompok Mata Kuliah Pengembangan Kepribadian yang meliputi 10 bagian, namun bila dibandingkan dengan daftar isi buku ini, terdapat beberapa pengembangan oleh penulisnya. Perbandingan amanat Keputusan Dirjen Dikti Nomor: 43/DIKTI/ Kep/2006 dengan isi buku mata kuliah Pendidikan Agama Islam untuk Perguruan Tinggi Umum yang disusun dosen agama UNG, dapat dilihat pada tabel berikut:

Tabel 2

Perbandingan Isi Dirjen Dikti dengan

Dosen Agama UNG

\begin{tabular}{|c|l|c|l|}
\hline \multicolumn{2}{|c|}{$\begin{array}{c}\text { DIRJEN DIKTI NO. 43/DIKTI/ } \\
\text { Kep/2006 }\end{array}$} & \multicolumn{2}{c|}{$\begin{array}{c}\text { Materi Kuliah PAIS untuk } \\
\text { perguruan tinggi umum UNG }\end{array}$} \\
\hline Bag. & \multicolumn{1}{|c|}{ Isi } & Bab & \multicolumn{1}{c|}{ Isi } \\
\hline A & $\begin{array}{l}\text { Tuhan Yang Maha Esa } \\
\text { - Keimanan dan } \\
\text { ketaqwaan }\end{array}$ & Bab I & $\begin{array}{l}\text { Konsep Ketuhanan Dalam } \\
\text { Islam }\end{array}$ \\
& - Filsafat ketuhanan & & $\begin{array}{l}\text { A. Pengertian Ketuhanan } \\
\text { (Teologi) }\end{array}$ \\
& & $\begin{array}{l}\text { B. Perkembangan } \\
\text { Pemikiran Manusia } \\
\text { Tentang tuhan }\end{array}$ \\
\hline
\end{tabular}

${ }^{20}$ Darwin Une, dkk. 2009. Materi Kuliah Pendidikan Agama Islam Untuk Perguruan Tinggi Umum. Gorontalo: UNG Prss, h. iv-v.

\begin{tabular}{|c|c|c|c|}
\hline & & & $\begin{array}{l}\text { C. Pemikiran Umat Islam } \\
\text { Tentang Tuhan } \\
\text { D. Keimanan dan } \\
\text { Ketakwaan } \\
\text { E. Ciri-Ciri Orang Beriman }\end{array}$ \\
\hline$B$ & $\begin{array}{l}\text { Manusia } \\
\text { - } \text { Hakikat manusia } \\
\text { - } \text { Martabat manusia } \\
\text { - } \quad \text { Tanggungjawab } \\
\quad \text { manusia }\end{array}$ & $\begin{array}{l}\text { Bab } \\
\text { II }\end{array}$ & $\begin{array}{l}\text { Manusia dan Agama } \\
\text { A. Hakikat Manusia } \\
\text { B. Agama dan Ruang } \\
\text { Lingkupnya }\end{array}$ \\
\hline$C$ & $\begin{array}{l}\text { Hukum } \\
\text { - } \text { Menumbuhkan } \\
\text { kesadaran untuk taat } \\
\text { hukum Tuhan } \\
\text { - } \begin{array}{l}\text { Fungsi profetik agama } \\
\text { dalam hokum }\end{array}\end{array}$ & $\begin{array}{l}\text { Bab } \\
\text { IV }\end{array}$ & $\begin{array}{l}\text { Hukum Islam dan Hak } \\
\text { Asasi Manusia } \\
\text { A. Hukum Islam } \\
\text { B. Sejarah Hak Asasi } \\
\text { Manusia }\end{array}$ \\
\hline$D$ & $\begin{array}{l}\text { Moral } \\
\text { - Agama sebagai sumber } \\
\text { moral } \\
\text { - Akhlak mulia dalam } \\
\text { kehidupan }\end{array}$ & $\begin{array}{l}\text { Bab } \\
\text { V }\end{array}$ & $\begin{array}{l}\text { Etika, Moral dan Akhlak } \\
\text { A. Pengertian Etika, Moral } \\
\text { dan Akhlak } \\
\text { B. Perbedaan Etika, Moral } \\
\text { dan Akhlak } \\
\text { C. Akhlak Mulia dalam } \\
\text { Kehidupan } \\
\text { D. Rasulullah Sebagai Suri } \\
\text { Teladan Yang Baik } \\
\text { E. Nilai-Nilai Akhlak Yang } \\
\text { Perlu Ditanamkan Sejak } \\
\text { Dini }\end{array}$ \\
\hline $\mathrm{E}$ & $\begin{array}{l}\text { Ilmu Pengetahuan, } \\
\text { Teknologi dan Seni } \\
\text { - Iman, ipteks dan amal } \\
\text { sebagai kesatuan } \\
\text { - Kewjiban menuntut } \\
\text { dan mengamalkan ilmu } \\
\text { - Tanggungjawab } \\
\text { ilmuwan dan seniman }\end{array}$ & $\begin{array}{l}\text { Bab } \\
\text { VI }\end{array}$ & $\begin{array}{l}\text { IImu Pengetahuan, } \\
\text { Teknologi dan Seni } \\
\text { A. Makna IPTEKS Dalam } \\
\text { Islam } \\
\text { B. Iman, Ilmu dan Amal } \\
\text { Sebagai Kesatuan } \\
\text { C. Kewajiban Menuntut } \\
\text { dan Mengamalkan IImu } \\
\text { D. Keutamaan Orang } \\
\text { Beriman dan Berilmu } \\
\text { E. Tanggung Jawab } \\
\text { Ilmuan Terhadap } \\
\text { Lingkungan }\end{array}$ \\
\hline $\mathrm{F}$ & $\begin{array}{l}\text { Kerukunan antar umat } \\
\text { beragama } \\
\text { - } \text { Agama merupakan } \\
\text { rahmat Tuhan bagi } \\
\text { semua } \\
\text { - } \text { Kebersamaan dalam } \\
\text { pluralitas beragama }\end{array}$ & $\begin{array}{l}\text { Bab } \\
\text { VII }\end{array}$ & $\begin{array}{l}\text { Kerukunan Antar Umat } \\
\text { Beragama } \\
\text { A. Agama Islam } \\
\text { Merupakan Rahmat } \\
\text { Bagi Semua Alam } \\
\text { Semesta } \\
\text { B. Ukhuwah Islamiyah } \\
\text { dan Ukhuwah } \\
\text { Insaniyah } \\
\text { C. Kebersamaan Dalam } \\
\text { Pluralitas Beragama } \\
\text { D. Amar Ma'ruf Nahi } \\
\text { Munkar }\end{array}$ \\
\hline
\end{tabular}




\begin{tabular}{|c|c|c|c|}
\hline$G$ & $\begin{array}{l}\text { Masyarakat } \\
\text { - Masyarakat beradab } \\
\text { dan sejahtera } \\
\text { - Peran umat beragama } \\
\text { dalam mewujudkan } \\
\text { masyarakat beradab } \\
\text { dan sejahtera } \\
\text { - Hak Asasi Manusia } \\
\text { (HAM) dan demokrasi }\end{array}$ & $\begin{array}{l}\text { Bab } \\
\text { VIII }\end{array}$ & $\begin{array}{l}\text { Masyarakat Madani } \\
\text { - Pendahuluan } \\
\text { - Konsep Masyarakat } \\
\text { Madani } \\
\text { - Sistem Ekonomi Islam } \\
\text { dan Kesejahteraan } \\
\text { Umat }\end{array}$ \\
\hline $\mathrm{H}$ & $\begin{array}{l}\text { Budaya } \\
\text { - Budaya akademik } \\
\text { - Etos kerja, sikap } \\
\text { terbuka dan adil }\end{array}$ & $\begin{array}{l}\text { Bab } \\
\text { IX }\end{array}$ & $\begin{array}{l}\text { Kebudayaan Islam } \\
\text { - Pendahuluan } \\
\text { - Definisi Kebudayaan } \\
\text { Dalam Islam } \\
\text { - Sejarah Intelektual } \\
\text { Islam } \\
\text { - Nilai-Nilai Islam Dalam } \\
\text { Budaya Indonesia } \\
\text { - Masjid Sebagai Pusat } \\
\text { Peradaban Islam }\end{array}$ \\
\hline I & $\begin{array}{l}\text { Politik } \\
\text { - Konstribusi agama } \\
\text { dalam kehidupan } \\
\text { berpolitik } \\
\text { - Peranan agama dalam } \\
\text { mewujudkan persatuan } \\
\text { dan kesatuan bangsa }\end{array}$ & $\begin{array}{l}\text { Bab } \\
\text { X }\end{array}$ & $\begin{array}{l}\text { Sistem Politik Islam } \\
\text { - Pendahuluan } \\
\text { - Pengertian Politik Islam } \\
\text { - } \text { Nilai-Nilai Dasar Sistem } \\
\text { Politik Dalam Al-Qur'an }\end{array}$ \\
\hline & \multicolumn{3}{|c|}{$\begin{array}{l}\text { Perbandingan antara SK Dirjen Dikti No. 43/Dikti } \\
\text { Kep/2006 khususnya pada bab III dengan daftar isi buk } \\
\text { Matakuliah Pendidikan Agama Islam yang disusun olel } \\
\text { dosen matakuliah Pendidikan Agama Islam UNG. }\end{array}$} \\
\hline
\end{tabular}

Dari tabel di atas, tampak dengan jelas ada penambahan satu bab (bab III) yakni Kerangka Dasar Agama Islam yang meliputi: aqidah, syariah, dan akhlak. Dimana hal tersebut tidak terdapat dalam keputusan DIKTI Nomor 43 tahun 2006. Dengan demikian, buku Matakuliah Pendididikan Agama Islam yang disusun oleh dosen UNG Gorontalo tersebut bertambah satu bab, dari 9 bagian pokok bahasan menjadi $10 \mathrm{bab}$ pokok bahasan.

Buku matakuliah ini diterbitkan pada 2009, dicetak terbatas hanya untuk kalangan sendiri. Sejak dicetak pertama kali, sampai kini belum pernah lagi dicetak ulang, belum ada cetakan baru, belum ada cetakan revisi. Cetakan revisi baru dalam tahap proses edit. Karena buku ini tidak dicetak lagi, maka buku tersebut tidak ditemukan lagi di toko buku, maupun koperasi kampus. Mahasiswa yang mengambil matakuliah agama hanya meminjam buku kepada kakak senior atau menfotocopy.

\section{Tadqiq Isi Buku Matakuliah PAI UNG}

Buku matakuliah ini tidak mengandung faham keagamaan diluar mainstream faham keagamaan di Indonesia. Hal ini dapat dimafhum karena dosen pengampu yang menulis buku ini berasal dari tokoh-tokoh adat Gorontalo dan juga pengurus organisasi (seperti NU dan Muhammadiyah).

Adapun yang ingin dilihat dari perspektif tadqiq adalah: translitaresi, penulisan ayat, penulisan hadis, literature (pengutipan dan daftar pustaka), dan keseragaman penulisan (kasus penulisan Al Qur'an, nama surah, nomor surah, dan nomor ayat).

\section{Transliterasi}

Transliterasi adalah sistem penulisan lambang bunyi. Secara bahasa, transliterasi berasal dari bahasa Inggris "transliteration", yang artinya, lambang bunyi, fonem atau kata dalam sistem penulisan, atau lambang yang ditentukan menurut aturan tata bahasa. ${ }^{21}$ Dalam Kamus Besar Bahasa Indonesia, transliterasi diartikan sebagai penyalinan dengan penggantian huruf abjad satu ke abjad yang lain. ${ }^{22}$ Jadi, transliterasi adalah penulisan atau pengucapan lambang bunyi bahasa asing yang dapat mewakili bunyi yang sama dalam sistem penulisan

\footnotetext{
${ }^{21}$ Peter Salim. 1996. The Contemporary EnglishIndonesian Dictionary. Jakarta: Modern English, h. 210.

${ }^{22}$ Tim Penyusun Kamus Pusat Pembinaan dan Pengembangan Bahasa. 1994. Kamus Besar Bahasa Indonesia. Jakarta: Balai Pustaka, h. 1070.
} 
suatu bahasa tertentu. Di Indonesia, transliterasi yang dimaksudkan adalah transliterasi Arab-Latin, yaitu penyalinan lambang bunyi huruf Arab ke dalam sistem penulisan huruf Latin. Pengalihhurufan itu harus dilakukan dengan cara-cara ilmiah dan sistematis. Tidak boleh ada pengurangan atau penambahan di dalamnya.

Trasnliterasi sangat banyak digunakan di berbagai negara, dengan berbagai aturan yang disepakati negara tersebut. Di Indonesia, telah ada aturan transliterasi berdasarkan Keputusan Bersama antara Menteri Agama dan Menteri Pendidikan dan Kebudayaan, No. 158 tahun 1987 dan No. $0543 \mathrm{~b} / \mathrm{u} / 1987$.

Huruf-huruf Arab dapat dilambangkan dengan tepat dalam huruf Latin. Agar bangsa Indonesi dapat membaca huruf Arab dengan fasih dalam huruf Latin. Membaca dengan fasih yang dimaksud adalah, membaca dengan baik dan benar sesuai kaidah tata bahasa Arab. Singkatnya, transliterasi di Indonesia diharapkan dapat membantu umat Islam dalam membaca, memahami dan menghayati sumber-sumber Islam yang berbahasa Arab.

Akan tetapi, sangat disayangkan buku Matakuliah Pendidikan Agama Islam yang digunakan di Universitas Negeri Gorontalo, belum menggunakan transliterasi sebagaimana yang diatur dalam Keputusan Bersama antara Menteri Agama dan Menteri Pendidikan dan Kebudayaan, No. 158 tahun 1987 dan No. 0543 b/u/1987.

\section{Penulisan Ayat}

Penulisan ayat dalam buku ini mengambil dari software Qur'an in word, jadi tidak ada masalah. Namun apabila tidak hati- hati, boleh jadi menimbulkan kerancuan, seperti tidak sepadannya antara teks ayat dengan terjemahnya. Kadang teks pendek dan terjemahnya panjang atau sebaliknya. Hal inilah yang terjadi dalam buku ini, (contoh pada hal. 1, teks ayat Al Qur'an ditulis secara utuh, sementara terjemahnya terpotong):

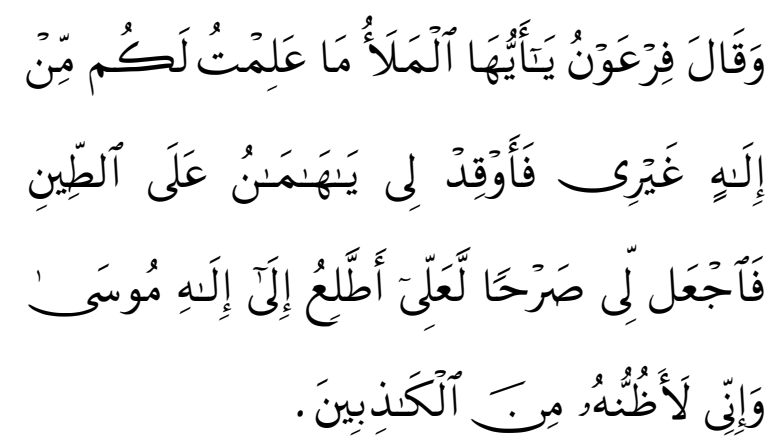

Artinya: "Dan berkata Fir'aun: "Hai pembesar kaumku, aku tidak mengetahui Tuhan bagimu selain aku" (Q.S. Al-Qasas : 38).

Seharusnya (artinya) dilengkapi sesuai dengan teks ayat:

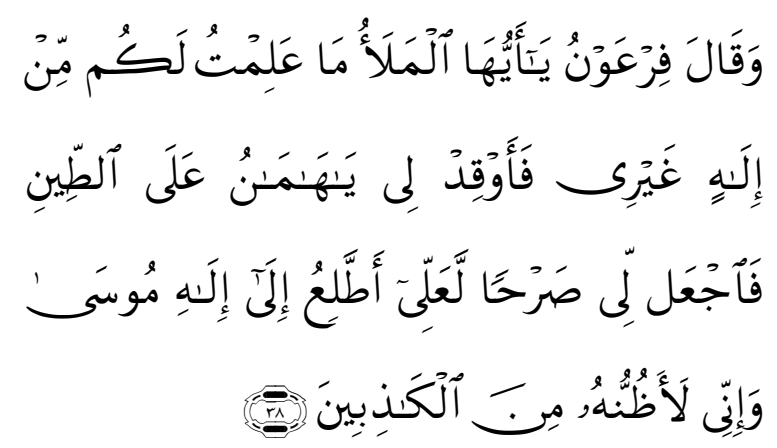

Artinya: 38. Dan berkata Fir'aun: "Hai pembesar kaumku, aku tidak mengetahui Tuhan bagimu selain aku. Maka bakarlah Hai Haman untukku tanah liat kemudian buatkanlah untukku bangunanyang Tinggisupaya aku dapat naik melihat Tuhan Musa, dan Sesungguhnya aku benar-benar yakin bahwa Dia Termasuk orang-orang pendusta". (QS. Al-Qasas /28: 38). 
Atau (ayat) ikut dipenggal sesuai dengan artinya:

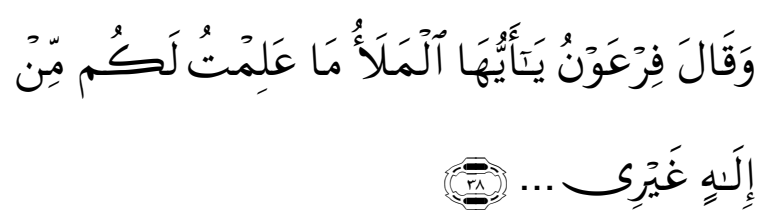

Artinya: 38. Dan berkata Fir'aun: "Hai pembesar kaumku, aku tidak mengetahui Tuhan bagimu selain aku.... (QS. Al-Qasas/28: 38).

Selanjutnya, terdapat kutipan ayat terlalu panjang tanpa menerjemahkannya. Contoh kasus pada hal. 125-126. Dalam buku ini mengutif QS. Al Mu'min/23:1-10. Namun oleh penulisnya mengikutkan terjemahan ayat 11 dari surah tersebut.

\section{Penulisan Hadis}

Hadis adalah sumber hukum kedua setelah Al Qur'an. Pada buku-buku ilmiah maupun non ilmiah, khususnya baku agama mengutip hadis. Demikian pula pada buku ini, banyak mengutip hadis. Ada beberapa kekurangan pengutipan hadis dalam buku ini, antara lain: tidak mencantumkan matan hadis, banyak yang tidak mencantumkan perawi hadis, tidak memakai transliterasi, ada yang hanya translitarasi ---itupun tidak mengikuti aturan transliterasi--- tanpa teks Arabnya, semua matan hadis tidak memakai harakat. Padahal pemakaian harakat sangat dibutuhkan oleh mahasiswa karena tidak semua mahasiswa dapat membaca teks tanpa harakat tersebut. Raihan, ${ }^{23}$ salah seorang mahasiswa Fakultas Ekonomi mengeluhkan hal tersebut karena dia mengaku dari SMU.

${ }^{23}$ Raihan, mahasiswa semester II pada Fakultas Ekonomi UNG. Wawancara pada tanggal 1 April 2016 di Kampus UNG
Selain itu, ada ungkapan yang diklaim sebagai hadis, salah satu contoh (hal. 22), tertulis: Al-Imaanu 'aqdun bil qalbi, waiqraarun billisaani wa'amalun bil arkaan (Al-Hadis).

Setelah peneliti mengecek akan kebenaran pernyataan tersebut pada kitab maktabah syamilah, matan tersebut tidak diketemukan. Yang ada adalah:

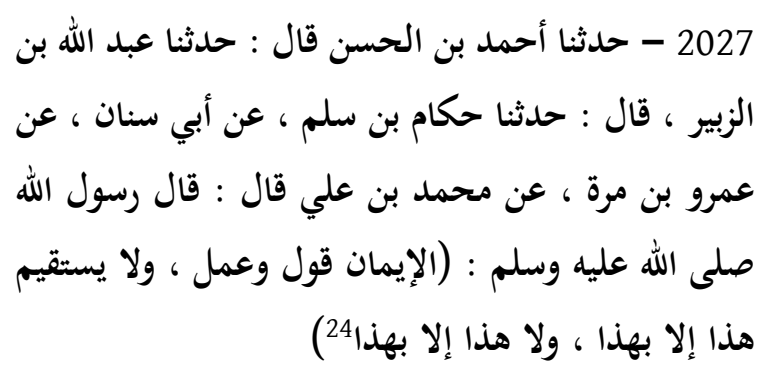

Masalah yang lain hampir sama adalah pernyataan pada hal. 152 yang berbunyi: 'Janganlah kencing di bawah pohon'. Isi hadis ini... pernyataan yang diklaim sebagai arti hardits tersebut tidak diketemukan dalam kitab hadis. Hadis yang diketemukan adalah yang hampir sama, yakni larangan kencing pada air tenang (tidak mengalir), larangan kencing pada lubang (di tanah), dan larangan kencing menghadap kiblat. Seperti pada hadis berikut:

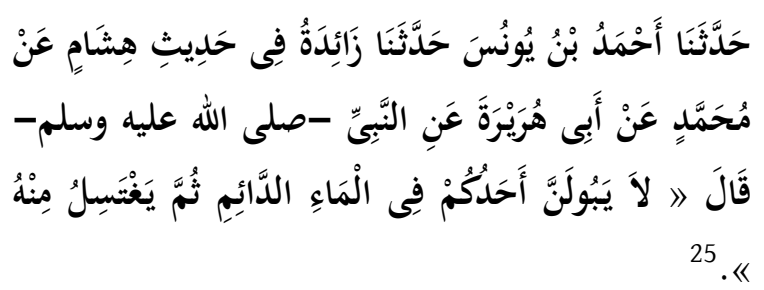

${ }^{24}$ Abu Ja'far Muhammad Ibn Jarir Ibn Yazid alTabari. Tth. Tahzib al-Asar Wa Tafsil al-Sabit 'An Rasuli Allahi min al-Akhbar. Kairo: Matba'ah alMadani, Juz II, h. 685.

${ }^{25}$ Abu Dawud Sulayman al-Asy'as, al-Sajastani. T.Th. Sunan Abi Dawud. Beirut: Dar al-Kitab al-'Arabi, Juz I, h. 26. 


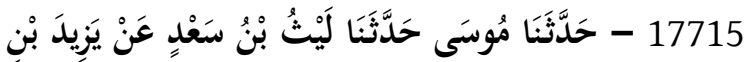

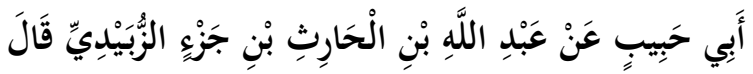

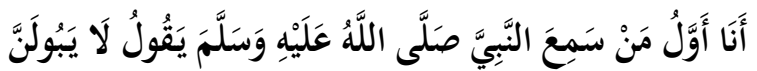

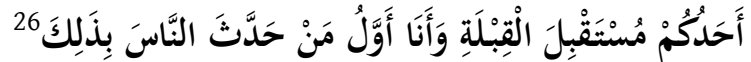
34 - أخبرنا عبيد الله بن سعيد قال أنبأنا معاذ بن هشام قال حدثني أبي عن قتادة عن عبد الله بن سرجس أن نبي

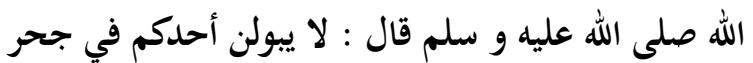
قالوا لقتادة وما يكره من البول في الجحر قال يقال إنها

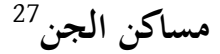

\section{Literatur (Pengutipan dan Daftar Pustaka)}

Daftar pustaka atau bibliografi menurut Kamus Besar Bahasa Indonesia (KBBI ${ }^{28}$ adalah daftar yang mencantumkan judul buku, nama pengarang, penerbit dan sebagainya yang ditempatkan pada bagian akhir suatu karangan atau buku dan disusun berdasarkan abjad. Daftar pustaka ini dikenal juga dengan nama buku rujukan atau mara>ji'. Mara>ji' sangat membantu bagi pembaca yang ingin melihat buku aslinya. Buku yang dimasukkan dalam daftar pustaka seyogyanya buku yang benar-benar dijadikan rujukan yang dibuktikan dalam footnote, innote atau endnote.

Buku matakuliah Pendidikan Agama Islam yang menjadi obyek tadqiq ini mempunyai 60 literatur pada daftar pustaka.

${ }^{26}$ Ahmad Ibn Hanbal. 1999. Musnad al-Imam Ahmad Ibn Hanbal. Kairo: Muassasah al-Risalah, Juz 29, h. 253.

${ }^{27}$ Ahmad Ibn Syu'aib Abu 'Abd al-Rahman alNisa'i. 1986. al-Mujtaba Min al-Sunan. Helb: Maktab al-Matbu'ah al-Islamiyyah, h. 8.

${ }^{28}$ Tim Penyusun Kamus Pusat Pembinaan dan Pengembangan Bahasa. 1994. Kamus Besar Bahasa Indonesia. Jakarta: Balai Pustaka, h 171
Penulisan daftar pustaka tidak seragam, banyak style yang digunakan. Dari 60 yang terdapat pada daftar pustaka tersebut, hanya 15 buku yang benar-benar dikutif dirujuk). Jadi masih ada 45 daftar pustaka hanya sekedar pajangan. Akan tetapi terdapat 15 kutipan (innote) yang tidak terdapat dalam daftar pustaka namun terdapat pada teks naskah. Ke-15 innote itu adalah:

1. (A.K. Brohi, 1982: 204) (hal. 105)

2. (Altaf Gauhar, 1983:345) (hal. 108)

3. (Baharuddin Lopa, 1996:1) (hal. 101)

4. (Hamidullah, 1970: 130) (hal. 107)

5. (Ibrahim Hosen, 1996:90) (hal. 100)

6. (M.A. Mannan, 1999:247) (hal. 215)

7. (Mohammad:33) (hal. 194)

8. (Muahammd Iqbal, 1968: 157) (hal. 109)

9. (Muhammad Ibn. Isma'al ashShan' any: 112

(hal. 214)

10. (Muhammad Iqbal, 1968: 173-174) (hal. 109)

11. (Safwan Idris, 1997:256) (hal. 198)

12. Charles J. Adam (hal. 30)

13. Ghazalba, (1975) (hal. 54)

14. Hasairin dan Hasbi ash Shiddiqie (hal. 89)

15. Syafruddin Prawiranegara (1967) (hal. 89)

Kutipan yang tidak terdapat dalam daftar pustaka inipun menggunakan banyak style penulisan. Dari 15 style penulisan tersebut hanya satu (yakni no. 4) yang memenuhi standar kaidah penulisan innote.

5. Keseragaman penulisan (kasus penulisan Al Qur'an, nama surah, nomor surah, dan nomor ayat).

Keseragaman penulisan dalam tulisan ilmiah mutlak adanya. Sebagai contoh ketidakseragaman penulisan dalam buku ini adalah penulisan nama surah, nomor surah, dan nomor ayat. Terdapat 75 style penulisan, yakni 36 model penulisan yang bersambung dengan terjemahan, dan 39 
model yang terpisah dengan terjemahan (dalam kalimat). Apaun 75 style atau model penulisan nama surah, nomor surah, dan nomor ayat dapat dilihat dala laporan lengkap.

\section{PENUTUP}

Buku Mata Kuliah PAIS di Universitas Negeri Gorontalo telah Sesuai dengan SK DIRJEN DIKTI NO. 43/DIKTI/Kep/2006. Ada penambahan dan pengurangan, namun tidak mengurangi konten buku tersebut. Buku mata kuliah tersebut diajarkan pada 11 Fakultas di UNG, tanpa memerhatikan jenis fakultas dan kelokalannya. Selain itu, buku ini dicetak sangat terbatas (kalangan sendiri).

Buku mata kuliah ini memiliki beberapa kekurangan yaitu: belum menggunakan transliterasi, ada beberapa kesalahan ketik, tidak konsisten dalam pengutipan ayat dan terjemahnya, hadis yang digunakan belum memenuhi standar penulisan (sanad, matan, perawi), tidak berharakat, dan ada yang mencantumkan hanya terjemahannya, dan ada ungkapan yang disinyalir sebagai hadis.

Berdasarkan temuan lapangan, maka penelitian ini merekomendasikan: a) Adanya buku mata kuliah Pendidikan Agama Islam di Perguruan Tinggi Umum (khususnya UNG) yang diterbitkan secara massal dengan mempertimbangkan fakultas, jurusan, dan kelokalan suatu daerah dimana PT tersebut berada; b) Buku/mata kuliah yang akan diterbitkan, seyogyanya ditadqiq oleh Kementerian Agama (cq. Lajah Pentashihan Mushaf Al Qur'an atau Puslit Lektur dan Khazanah Keagamaan), sehingga buku matakuliah tersebut benar-benar sudah memenuhi standar buku ilmiah populer.

\section{UCAPAN TERIMA KASIH}

Banyak orang yang ikut membantu sampai akhirnya tulisan ini dapat dirampungkan dengan baik. dari itu penulis menyampaikan banyak terima kasih kepada Bapak Kepala Balai Penelitian dan Pengembangan Agama Makassar yang telah menfasilitasi pada penelitian ini. selanjutnya penulis sampaikan terimam kasih kepada para dosen Agama Islam Pada Universitas Negeri Gorontalo yang menjadi informan dalam penelitian ini, dan semua rekanrekan pada bidang lektur dan khazanah keagamaan Balitbang Agama Makassar. terakhir kami ucapkan terima kasih kepada pengurus Jurnal Edukasi atas dimuatnya tulisan ini.

\section{DAFTAR PUSTAKA}

Al-Qur'an dan Terjemahnya. (1418): H. Madinah: Mujamma' Malik Fahd li Thaba'ati al Mushaf asy Syarif.

'Abd al-Tawwab, Ramadan. (1985): Manahij Tahqiq al-Turas Bain al-Qudama Wa alMuhdasin. Kairo: Maktabah al-khanijiy.

al-Nisa'i, Ahmad Ibn Syu'aib Abu 'Abd alRahman. (1986). al-Mujtaba Min alSunan. Helb: Maktab al-Matbu'ah alIslamiyyah.

al-Sajastani, Abu Dawud Sulayman al-Asy'as. T.Th. Sunan Abi Dawud. Beirut: Dar alKitab al-'Arabi, Juz I.

al-Tabari , Abu Ja'far Muhammad Ibn Jarir Ibn Yazid. Tth. Tahzib al-Asar Wa Tafsil al-Sabit 'An Rasuli Allahi min al-Akhbar. Kairo: Matba'ah al-Madani, Juz II. 
Baried, Siti Barorah. et al., (1994): Pengantar Teori Filologi. Yoyakarta, Badan Penelitian dan dan Publikasi Fakultas Seksi Filologi Fakultas Sastra Universitas Gadjah Mada.

Darwin Une, dkk. (2009): Materi Kuliah Pendidikan Agama Islam Untuk Perguruan Tinggi Umum. Gorontalo, UNG Prss.

Hasanuddin, dkk. (2012): Sejarah Pendidikan di Gorontalo. Yogyakarta, Kepel Presss.

http://www.ung.ac.id/profil/aboutprofil diunduh tanggal 23 April 2016

http://www.ung.ac.id/profil/visimisi diunduh tanggal 21 April 2016

Ibn Hanbal, Ahmad. (1999): Musnad al-Imam Ahmad Ibn Hanbal. Kairo: Muassasah alRisalah, Juz 29.

Keputusan Bersama antara Menteri Agama dan Menteri Pendidikan dan Kebudayaan, No. 158 tahun 1987 dan No. 0543 b/u/1987.

Keputusan Dirjen Dikti Nomor: 43/DIKTI/ Kep/2006 dengan isi buku mata kuliah Pendidikan Agama Islam untuk Perguruan Tinggi Umum.

Keputusan Kepala Badan Litbang Agama dan Diklat Keagamaan No. BD/01/2004, Tanggal 5 Februari 2004 tentang Pedoman Penulisan, Penerbitan, dan Pentashihan Buku-Buku Keagamaan.

Keputusan Mentari Agama Republik Indonesia, No. 437 Tahun 2001, Tanggal 8 Oktober 2001 tentang Pentashihan Buku-Buku yang Memuat Tulisan AyatAyat Al-Qur'an yang Diterbitkan, dan Diadakan di Lingkungan Depertemen Agama.

Laporan hasil penelitian Balitbang Agama Makassar. (2015): Pergeseran Faham Keagamaan Mahasiswa Di Kampus Kawasan Timur Indonesia. Makassar, Balitang Agama Makassar.
Munawiroh. (2009): "Kajian atas Buku Teks Pendidikan Agama Islam pada Madrasah Ibtidaiyah", dalam Jurnal Lektur Keagamaan,Vol. 7, No. 2, h. 293312

Saefullah, Asep dan Masmedia Pinem (Ed.), (2007): Panduan Pentashihan Buku Keagamaan. Jakarta: Puslitbang Lektur Keagamaan Badan Litbang dan Diklat.

Salim, Peter. (1996): The Contemporary English-Indonesian Dictionary. Jakarta: Modern English.

Tim Penyusun Kamus Pusat Pembinaan dan Pengembangan Bahasa. 1994. Kamus Besar Bahasa Indonesia. Jakarta: Balai Pustaka.

Undang-undang Nomor 20 Tahun 2003 Tentang Sistem Pendidikan Nasional.

UU RI No. 38 Tahun 2000 tentang pembentukan Provinsi Gorontalo.

Yunardi, Badri. (2005): "Pokok-Pokok Pikiran tentang Pengembangan Tugas Pentashihan Buku-Buku Keagamaan”, disampaikan pada Workshop Pedoman Pentashihan Buku Keagamaan, Puslitbang Lektur Agama, tanggal 2930 Nopember 2005 di Gedung Bayt Al-Qur'an dan Museum Istiqlal, TMII, Jakarta.

Informan:

Agil Bahsoan, dosen matakuliah Pendidikan Agama Islam di UNG. Wawancara pada tanggal 29 Maret 2016 di Rektorat UNG.

Lukman D. Katili, dosen matakuliah Pendidikan Agama Islam di UNG. Wawancara pada tanggal 29 Maret 2016 di Rektorat UNG.

Raihan, mahasiswa semester II pada Fakultas Ekonomi UNG. Wawancara pada tanggal 1 April 2016 di Kampus UNG 